\title{
Avaliação Físico-Química, Microbiológica e Sensorial de Leites Comercializados no Município de Belmiro Braga-MG
}

\author{
Aline Santos Zago Cunha (I), Arianne de Souza Castro (I), Emília \\ Maricato Pedro dos Santos (I), Edilene Bolutari Baptista (I), Carolina \\ dos Santos Fernandes da Silva (I) \\ (I) UNIPAC - Universidade Presidente Antônio Carlos (Av. Juiz de Fora, 1100 - bairro Granjas \\ Bethânia - Juiz de Fora, MG)
}

\section{Resumo}

O leite, por sua composição, é considerado um dos alimentos mais fundamentais para dieta humana, mas, pela mesma razão, constitui num excelente substrato para o desenvolvimento de uma grande diversidade de micro-organismos, inclusive os patogênicos. Dessa forma, a qualidade do leite consiste em uma constante preocupação para técnicos e autoridades ligadas à área de saúde, principalmente pelo risco de veiculação de microorganismos relacionados às doenças transmitidas por alimentos. $\mathrm{O}$ objetivo do presente trabalho foi realizar análises físico-químicas e microbiológicas de leites comercializados no município de Belmiro Braga - MG, a fim de avaliar a qualidade dos mesmos oferecidos à população. Foram avaliadas amostras de leite pasteurizado, ultrapasteurizado e cru por meio das seguintes análises microbiológicas: determinação de coliformes a $35^{\circ} \mathrm{C}$ e a $45^{\circ} \mathrm{C}$, pela técnica dos tubos múltiplos (NMP), pesquisa de Salmonella spp., e contagem de bactérias aeróbias mesófilas, por meio de diluições seriadas e semeadas em Agar Padrão para Contagem Bacteriana Total.Já para avaliar a qualidade físico-química, foram realizadas as provas de acidez titulável, estabilidade ao álcool-alizarol $72 \%$, densidade a $15^{\circ} \mathrm{C}$, pesquisa de peróxido de hidrogênio, pesquisa de alcalinos, pesquisa de amido, e pesquisa das enzimas fosfatase alcalina e lactoperoxidase. Foi realizada, ainda, a análise sensorial das amostras de leite pasteurizado e 
ultrapasteurizado, sendo aplicado o teste de preferência (escala hedônica de 9 pontos) e o teste Analítico Discriminatório Triangular, ambos contando com a participação de provadores não-treinados de ambos os sexos. Os resultados obtidos demonstram que as amostras estudadas, em seus aspectos microbiológicos e físico-químicos, encontram-se de acordo com a legislação brasileira vigente.Neste ensaio $100 \%$ das amostras de leite pasteurizado e cru apresentaram determinação de coliformes a $35^{\circ} \mathrm{C} \mathrm{e}$ coliformes a $45^{\circ} \mathrm{C}$, bactérias aeróbias mesófilas e Salmonella spp.dentro do preconizado pela Instrução normativa 62/2011, do Ministério da Agricultura, Pecuária e Abastecimento. Já a análise sensorial demonstrou uma preferência dos provadores pelo leite ultrapasteurizado e uma deficiência na percepção da diferença dos tipos de leite. Dessa forma, podese inferir aspecto positivo para a população e manipuladores de leite do muncípio de Belmiro Braga - MG, os quais estão agindo dentro dos padrões higiênicos recomendados para o manuseio do leite.

Palavras-Chave: Qualidade do leite, leite cru, leite pasteurizado, leite ultrapasteurizado

\section{Agência de Fomento:}

